\title{
Analisis Prestasi Pendidikan Anak Penerima Bantuan Program Keluarga Harapan Di Kecamatan Peranap Kabupaten Indragiri Hulu
}

\author{
Andrel Rosevelt ${ }^{* 1}$, B. Isyandi ${ }^{2}$, Sri Endang Kornita ${ }^{3}$ \\ Pascasarjana Ilmu Ekonomi Universitas Riau \\ Korespondensi: andrel.rosevelt@gmail.com
}

\begin{abstract}
Abstrak
Penelitian ini bertujuan untuk menganalisis prestasi pendidikan anak penerima bantuan Program Keluarga Harapan di Kecamatan Peranap Kabupaten Indragiri Hulu dan untuk mengetahui faktor-faktor yang mempengaruhinya. Penelitian ini merupakan penelitian primer yang pengumpulan datanya menggunakan kuesioner penelitian. Jumlah populasi penelitian adalah seluruh keluarga penerima bantuan program keluarga harapan dalam peran peran Kabupaten Indragiri Hulu yaitu sebanyak 446 kepala keluarga, maka berdasarkan rumus Slovin dengan taraf 10\% maka jumlah sampel berjumlah 82 responden dimana responden terbagi dalam keluarga yang telah memilih anak sekolah yaitu pendidikan anak penerima PKH tertinggi. Metode analisis yang digunakan adalah deskriptif kuantitatif dengan menggunakan analisis regresi linier berganda. Berdasarkan hasil penelitian diketahui bahwa bantuan Program Keluarga Harapan (PKH) berpengaruh positif signifikan terhadap prestasi belajar anak penerima Program Keluarga Harapan (PKH) di Kecamatan Peranap Kabupaten Indragiri Hulu. Tingkat kehadiran anak berpengaruh positif signifikan terhadap prestasi pendidikan anak penerima Program Keluarga Harapan (PKH) di Kecamatan Peranap Kabupaten Indragiri Hulu. Pendapatan orang tua berpengaruh positif signifikan terhadap prestasi pendidikan anak penerima Program Keluarga Harapan (PKH) di Kecamatan Peranap Kabupaten Indragiri Hulu. Jika pendapatan orang tua meningkat maka akan meningkatkan prestasi pendidikan anak penerima Program Keluarga Harapan (PKH) di Kecamatan Peranap Kabupaten Indragiri Hulu. Dan tingkat pendidikan orang tua berpengaruh positif signifikan terhadap prestasi pendidikan anak penerima Program Keluarga Harapan (PKH) di Kecamatan Peranap Kabupaten Indragiri Hulu.
\end{abstract}

Kata kunci: Prestasi Anak, Penerima PKH, Pendidikan Orang Tua, Pendapatan Orang Tua

This study aims to analyze the educational achievements of children who receive assistance from the Hope Family Program in the Peranap District, Indragiri Hulu Regency and to find out the factors that influence it. This research is a primary research that collects data using a research questionnaire. The total population of the study was all families receiving the family hope program assistance in the role of the role of the Indragiri Hulu Regency, namely as many as 446 families, then based on the Slovin formula with a level of 10\%, the total sample size was 82 respondents in which the respondents were divided into families who have selected school children, namely the highest PKH recipient child education. The analytical method used is descriptive quantitative using multiple linear regression analysis. Based on the results of the study, it is known that the Family Hope Program (PKH) assistance has a significant positive effect on the educational achievement of children receiving the Hope Family Program (PKH) in Peranap District, Indragiri Hulu Regency. The level of attendance of children has a significant positive effect on the educational achievement of children receiving the Hope Family Program (PKH) in the Peranap District, Indragiri Hulu Regency. Parents' income has a significant positive effect on the educational achievement of children receiving the Hope Family Program (PKH) in the Peranap District, Indragiri Hulu Regency. If the parents' income increases, it will increase the educational achievement of children who receive the Hope Family Program (PKH) in Peranap District, Indragiri Hulu Regency. And the level of parental education has a significant positive effect on the educational achievement of children receiving the Hope Family Program (PKH) in the Peranap District, Indragiri Hulu Regency.

Keywords: Children's Achievement, PKH Recipients, Parents 'Education, Parents' Income 


\section{PENDAHULUAN}

Pembangunan ekonomi merupakan usaha untuk meningkatkan taraf hidup suatu bangsa yang seringkali diukur dengan tinggi rendahnya pendapatan riil perkapita. Artinya pembangunan ekonomi selain bertujuan menaikan pendapatan riil juga meningkatkan produktivitas.Pembangunan suatu bangsa memerlukan dua asset atau daya yang di kenal dengan sumber daya (resources) salah satunya yaitu sember daya manusia (human resources), jika di kembangkan maka akan menentukan keberhasilan pembangunan. Sumber daya manusia sendiri terdiri dari kuantitas yang menyangkut jumlah sumber daya manusia, namun kuantitas sumber daya manusia harus di ikuti dengan kualitas sumber daya manusia jika tidak terpenuhi maka akan memicu beban pembangunan (Notoatmodjo, 2015).

Pentingnya sumber daya manusia dalam perekonomian di jelaskan oleh teori pertumbuhan ekonomi Model Solow yang mengatakan bahwa sumber daya manusia memiliki peranan penting dalam mendorong tingkat produksi yang selanjutnya menciptakan pertumbuhan ekonomi (Mulyadi, 2017).

Menurut (Mulyadi, 2017) dalam pembangunan sumber daya manusia menjadi salah satu pokok yang harus di perhatikan, sehingga kualitas SDM menjadi hal penting untuk di kaji. Kualitas SDM menyangkut dua aspek yaitu aspek fisik dan aspek non fisik yang menyangkut kemampuan bekerja dan berfikir. Selain itu, kualitas SDM di tentukan oleh salah satu faktor yaitu pendidikan. Sehingga dalam peningkatan kualitas SDM di lakukan dengan penguasaan ilmu pengetahuan.

Pendidikan merupakan suatu upaya mengembangan potensi manusia, sehingga mempunyai kemampuan untuk mengelola sumber daya manusia di suatu negara untuk mewujudkan kesejahteraan masyarakat (Notoatmodjo, 2015). Hal ini menjelaskan bahwa pendidikan merupakan ujung tombak dalam pembangunan ekonomi.

Pentingnya pendidikan dalam mendorong kesejahteraan, hal tersebut di jelaskan dalam human capital theory menurut (Frank \& Bernanke, 2007) berpendapat bahwa perpaduan antara pendidikan, pengalaman, pelatihan, keterampilan, kebiasaan, kesehatan, energi dan inisiatif yang memengaruhi produktivitas manusia. Selain itu, (Todaro \& Smith., 2013) mengungkapkan bahwa human capital dapat diukur salah satunya melalui bidang pendidikan. Pendidikan menjadi nilai tambah bagi sumber daya manusia. Dimana semakin tinggi pendidikan seseorang maka kemampuan dan keterampilan yang dimiliki semakin tinggi. Sehingga teori ini menjelaskan bahwa pendidikan merupakan salah satu modal pembangunan SDM, dengan peningkatan pendidikan maka akan mendorong kualitas SDM yang selanjutnya meningkatkan mutu SDM serta mendorong produktivitas SDM dan meningkatkan kesejahteraan.

Melihat kondisi demikian, mendorong pemerintah untuk mengambil kebijakan yang berhubungan dengan peningkatan kualitas SDM, terutama terkait SDM yang memiliki keterbatasan atau tidak mampu dalam memperoleh pendidikan yang baik dan berkualitas. Terlebih lagi, dalam mewujudkan tercapainya pertumbuhan dan pembangunan kualitas SDM tentunya peran pemerintah pusat maupun daerah sangat di butuhkan, hal tersebut karena sangat pentingnya campur tangan pemerintah terutama dalam berbagai aspek yang nantinya dapat mendorong kualitas SDM (Isyandi, 2014).

Salah satu bentuk kebijakan yang di lakukan pemerintah yaitu Program Perlindungan Sosial yang juga dikenal di dunia internasional dengan istilah Conditional Cash Transfers (CCT) ini terbukti cukup berhasil terhadap sosial ekonomi yang dihadapi di beberapa Negara salah satunya di Meksiko hasil penelitian Skoufias dan Susan dimana program Conditional Cash Transfers (CCT) di meksiko dapat meningkatkan kualitas pendidikan.

Program Keluarga Harapan (PKH) membuka akses keluarga miskin salah satunya yaitu fasilitas layanan pendidikan (fasdik) yang tersedia di sekitar mereka. Melalui Program Keluarga Harapan (PKH), KM didorong untuk memiliki akses dan memanfaatkan pelayanan sosial dasar khusunya pendidikan. Tingginya angka putus sekolah menyebabkan peringkat indeks pembangunan rendah. Oleh karena itu mendorong anak untuk tetap bersekolah pada usia remaja menjadi hal mendasar. Keikutsertaan mereka 
yang berada di luar sistem sekolah pun harus menjadi hal mendasar. Keikutsertaan mereka yang berada di luar sistem sekolah pun harus menjadi perhatian utama.

Provinsi Riau sendiri terdiri dari 12 kabupaten/kota, yang mana salah satunya adalah Kabupaten Indragiri Hulu, yang mana Kementrian Sosial melalui Dinas Sosial melaksanakan penyaluran Program Keluarga Harapan (PKH) yang bertujuan untuk menanggulangi kemiskinan

Sedangkan pada hakikatnya tujuan dari pemberian Program Keluarga Harapan (PKH) bagi anak yang bersekolah di fokuskan pada wajib sekolah 12 tahun, sehingga anak akan memperoleh bantuan biaya untuk pendidikan sesuai dengan tingkatan pendidikan, sehingga tidak ada lagi yang namanya anak putus sekolah. Selain itu, juga di harapkan anak sekolah yang telah menyelesaikan pendidikan wajib 12 tahun untuk dapat melanjutkan pendidikan ke perguruan tinggi dengan prestasi yang di miliki melalui bantuan bidik misi.

Perkembangan rata - rata lama sekolah di Provinsi Riau terus mengalami peningkatan, dimana pada tahun 2019 mencaai 9,03 tahun, akan tetapi angka tersebut masih jauh dibawah target yang ingin di capai yaitu wajib belajar 12 tahun. Selain itu jika dilihat dari perkembangan rata - rata lama sekolah menurut Kabupaten/kota, terdapat 3 daerah dengan angka rata - rata lama seolah terendah, salah satunya yaitu Kabupaten Indragiri Hulu yaitu 8,17 tahun.

Melihat kondisi demikian menjelaskan bahwa dalam mewujudkan pembangunan SDM melalui peningkatan kualitas dan mutu SDM itu sendiri di lakukan salah satu faktor pendorong yaitu bidang pendidikan, pendidikan merupakan salah satu modal pembangunan manusia sehingga mendorong pemerintah untuk memberikan kebutuhan pendidikan yang sama bagi masyarakat miskin melalui program $\mathrm{PKH}$, yang selanjutnya akan mendorong prestasi anak penerima bantuan tersebut.

Menurut Gary Dessler menjelaskan bahwa prestasi adalah hasil kerja yang di capai seseorang dalam melaksanakan tugas yang di bebankan. Begitu juga halnya dengan prestasi sekolah yaitu hasil dari kegiatan pembelajaran yang di jalani (Isyandi, 2004).

Tingkat sosial yaitu tingkat pendidikan orang tua merupakan faktor yang akan memberi pengalaman kepada anak dan menimbulkan perbedaan dalam minat, apresiasi sikap dan pemahaman ekonomis, perbendaharaan bahasa, abilitas berkomunikasi dengan orang lain, motif berfikir, kebiasaan berbicara dan pola hubungan kerjasama dengan orang lain. Perbedaan-perbedaan ini akan sangat berpengaruh dalam tingkah laku dan perbuatan dalam kegiatan belajar mengajar di sekolah (Hamalik, 2002).

Berikut ini dapat dilihat jumlah Keluarga Miskin (KM) Program Keluarga Harapan (PKH), angka partisipasi sekolah (APS), rata - rata lama sekolah dan PDRB per kapita menurut jenjang pendidikan di Kabupaten Indragiri Hulu Tahun 2015 - 2019 :

Tabel 1. Jumlah KPM PKH, Angka Partisipasi Sekolah Menurut umur, Rata - Rata Lama Sekolah Dan PDRB Per Kapita di Kabupaten Indragiri Hulu Tahun 2015 - 2019

\begin{tabular}{cccccccc}
\hline No & Tahun & $\begin{array}{c}\text { KPM } \\
\text { PKH }\end{array}$ & \multicolumn{3}{c}{$\begin{array}{c}\text { APS Menurut Umur Sekolah } \\
\text { (Tahun) }\end{array}$} & $\begin{array}{c}\text { Rata - Rata } \\
\text { Lama } \\
\text { Sekolah }\end{array}$ & $\begin{array}{c}\text { PDRB Per } \\
\text { Kapita } \\
\text { (Juta Rp) } \\
\text { (Tahun) }\end{array}$ \\
\hline 1 & 2015 & 3.660 & 99,48 & 92,41 & 65,37 & 7,82 & 61,49 \\
\hline 2 & 2016 & 6.400 & 99,70 & 94,49 & 80,13 & 7,83 & 62,52 \\
\hline 3 & 2017 & 6.267 & 99,17 & 94,27 & 77,95 & 7,89 & 63,87 \\
\hline 4 & 2018 & 9.894 & 99,53 & 95,27 & 74,56 & 8,16 & 65,00 \\
\hline 5 & 2019 & 9.535 & 99,57 & 95,71 & 73,79 & 8,17 & 66,31 \\
\hline
\end{tabular}

Sumber: PKH.Dinsos INHU dan Badan Pusat Statistik, 2020 
Jika di lihat perkembangan penerima bantuan PKH atau KPM PKH di Kabupaten Indragiri Hulu terus mengalami peningkatan dari tahun 2015 - 2018, namun kondisi berbeda justru terlihat pada angka partisipasi sekolah (APS) justru berfluktuatif. Sedangkan seharusnya dengan adanya program sosial yang bertujuan untuk meningkatkan kualitas SDM melalui pendidikan maka akan mendorong peningkatan partisipasi sekolah (APS) di daerah tersebut. Namun, kondisi berlawanan justru terlihat di Kabupaten Indragiri hulu.

Jika dilihat dari perkembangan data rata - rata lama sekolah dan PDRB per kapita cenderung mengalami peningkatan, tetapi angka partisipasi sekolah (APS) menurut jenjang pendidikan justru berfluktuatif. Begitu juga halnya dengan kondisi penerima PKH mengalami peningkatan sejak tahun 2015 - 2019, namun angka partisipasi sekolah (APS) menurut jenjang pendidikan justru berfluktuatif di Kabupaten Indragiri Hulu.

Sehingga perlu nya di lakukan penelitian lebih lanjut terkait pembangunan kualitas SDM di Kabupaten Indragiri Hulu dalam aspek pendidikan yang di lihat dari prestasi anak penerima PKH berdasarkan jenjang pendidikan. Sedangkan dalam penelitian ini penulis menfokuskan kepada salah satu kecamatan yang terdapat di Kabupaten Indragiri Hulu, sebagaimana diketahui bahwa Kabupaten Indragiri Hulu terdiri dari 13 Kecamatan, yang mana salah satu kecamatan nya adalah Kecamatan peranap.

Kabupaten Indragiri Hulu terdiri dari 14 Kecamatan, yang mana keluarga miskin (KM) penerima bantuan program keluarga harapan $(\mathrm{PKH})$ tersebar diseluruh kecamatan tersebut. Berikut ini dapat dilihat keluarga miskin $(\mathrm{KM})$ penerima bantuan program keluarga harapan $(\mathrm{PKH})$ menurut kecamatan di Kabupaten Indragiri Hulu Tahun 2019 :

Tabel 2 Keluarga Miskin (KM) Penerima Bantuan Program Keluarga Harapan (PKH) Menurut Kecamatan di Kabupaten Indragiri Hulu Tahun 2019

\begin{tabular}{clc}
\hline No & \multicolumn{1}{c}{ Kecamatan } & $\begin{array}{c}\text { KM penerima bantuan program keluarga harapan (PKH) } \\
(\mathrm{KK})\end{array}$ \\
\hline 1 & Batang Cenaku & 699 \\
\hline 2 & Batang Gansal & 887 \\
\hline 3 & Batang Peranap & 279 \\
\hline 4 & Kelayang & 738 \\
\hline 5 & Kualu Cenaku & 718 \\
\hline 6 & Lirik & 323 \\
\hline 7 & Lubuk Batu Jaya & 271 \\
\hline 8 & Pasir Penyu & 554 \\
\hline 9 & Peranap & 446 \\
\hline 10 & Rakit Kulim & 1377 \\
\hline 11 & Rengat & 662 \\
\hline 12 & Rengat Barat & 1076 \\
\hline 13 & Seberida & 605 \\
\hline 14 & Sungai Lala & 465 \\
\hline
\end{tabular}

Sumber: Dinas Sosial INHU, 2020

Berdasarkan Tabel 2 di atas dapat diketahui bahwa salah satu dari 14 kecamatan tersebut yang merupakan 5 kecamatan penerima bantuan program keluarga harapan (PKH) adalah Kecamatan Peranap. Melihat kondisi demikian maka penulis menfokuskan penelitian pada Kecamatan Peranap Kabuapaten Indragiri Hulu.

Kajian terkait dengan anak bantuan program keluarga harapan $(\mathrm{PKH})$ dengan prestasi sekolah telah di lakukan oleh peneliti sebelumnya salah satunya (Suparno, 2018) menjelaskan bahwa anak 
penerima Program Keluarga Harapan (PKH) mendapatkan pendidikan yang layak serta memperoleh prestasi belajar anaknya meningkat dilihat dari prestasi yang diperoleh ditIngkat lokal, nasional dan internasional. Namun, dalam penelitian ini menambahkan variable dari aspek sosial dan ekonomi keluarga.

Selain itu, penelitian terkait pengaruh pendapatan orang tua terhadap prestasi belajar dilakukan oleh (Menhard, 2017) yang mana menemukan hasil bahwa pendapatan orang tua berpengaruh terhadap pendidikan sedangkan (Hadiyanto, 2014) justru menunjukkan bahwa pendapatan orang tua berpengaruh positif terhadap prestasi sekolah. Selain itu (Ani \& Marbuah, 2016) yang menunjukkan bahwa pendidikan orang tua berpengaruh negatif terhadap prestasi sekolah anak. Yang membedakan penelitian ini dengan penelitian sebelumnya adalah objek penelitian yang memfokuskan kepada anak sekolah yang berasal dari keluarga miskin penerima bantuan sosial pemerintah atau program keluarga harapan (PKH).

\section{METODE}

Penelitian ini di lakukan di Kecamatan Peranap Kabupaten Indragiri Hulu dengan menggunakan data primer, adapun lokasi penelitian di pilih karena Kecamatan Peranap merupakan daerah yang mengembangkan atau menerima bantuan Program Keluarga Harapan (PKH) terutama dalam aspek pendidikan. Waktu penelitian akan dimulai dari Juli 2020.

Teknik pengumpulan data yang digunakan dalam penelitian ini adalah: Angket atau Kuesioner. Populasi dalam penelitian ini adalah seluruh keluarga miskin $(\mathrm{KM})$ penerima bantuan program keluarga harapan (PKH) di Kecamatan Peranap Kabupaten Indragiri Hulu Provinsi Riau, yaitu sebanyak 446 KK. Dengan demikian jumlah sampel dalam penelitian ini menggunakan perhitungan rumus Slovin, Maka sampel yang digunakan sebanyak $82 \mathrm{KK}$.

\section{Definisi Operasioanl Variabel}

Ruang lingkup penelitian ini mencakup program Program Keluarga Harapan (PKH) alam meningkatkan prestasi pendidikan anak penerima bantuan PKH di Kecamatan Peranap Kabupaten Indragiri Hulu.. Untuk lebih memudahkan pembahasan maka penulis membatasi variable, berikut ini dapat di lihat defenisi operasional penelitian:

Tabel 3 Definisi Operasional Penelitian

\begin{tabular}{|c|c|c|c|c|}
\hline No & Variabel & Pengertian & Indikator & Satuan \\
\hline 1 & $\begin{array}{l}\text { Prestasi } \\
\text { pendidikan }\end{array}$ & $\begin{array}{lr}\text { Capaian } & \text { dari } \\
\text { pendidikan yang di } \\
\text { jalani. Yang dapat } \\
\text { dilihat dari perolehan } \\
\text { nilai sekolah yang } \\
\text { dimiliki oleh anak } \\
\text { sekolah. }\end{array}$ & $\begin{array}{l}\text { Nilai pendidikan yang di peroleh. } \\
\text { Adapun nila yang dimaksud } \\
\text { adalah nilai rata - rata rapor anak } \\
\text { pada saat semester terakhir } \\
\text { penelitian. Yang mana penelitian } \\
\text { di lakukan pada bulam juni } \\
\text { hingga juli, pada saat tersebut } \\
\text { masih proses pembelajar. } \\
\text { Sehingga semester yang di ambil } \\
\text { yaitu semester yang terakhir } \\
\text { dituntaskan yaitu genap } 2019 \text {. }\end{array}$ & Skore \\
\hline 2 & $\begin{array}{l}\text { Bantuan } \\
\text { PKH } \\
\text { Bidang }\end{array}$ & $\begin{array}{lr}\text { Dana } & \text { yang } \\
\text { dialokasikan } & \\
\text { oleh PKH } & \text { kepada }\end{array}$ & $\begin{array}{l}\text { Jumlah bantuan yang di peroleh } \\
\text { anak setiap bulan. }\end{array}$ & $\mathrm{Rp}$ \\
\hline
\end{tabular}




\begin{tabular}{|c|c|c|c|}
\hline & Pendidikan & $\begin{array}{lll}\text { RTSM } & \text { untuk } & \text { anak } \\
\text { sekolah } & & \\
\end{array}$ & \\
\hline 3 & $\begin{array}{l}\text { Tingkat } \\
\text { Kehadiran }\end{array}$ & $\begin{array}{l}\text { Tingkat kehadiran } \\
\text { merupakan kedatangan } \\
\text { anak dalam setiap } \\
\text { pembelajaran }\end{array}$ & $\begin{array}{l}\text { Persentase kehadiran penuh. } \% \\
\text { Yaitu persentase kehadiran. ir } \\
\text { penelitian. Yang mana penelitian } \\
\text { di lakukan pada bulam juni } \\
\text { hingga juli, pada saat tersebut } \\
\text { masih proses pembelajar. } \\
\text { Sehingga semester yang di ambil } \\
\text { yaitu semester yang terakhir } \\
\text { dituntaskan yaitu genap 2019 }\end{array}$ \\
\hline 4 & $\begin{array}{l}\text { Pendapatan } \\
\text { orang Tua }\end{array}$ & $\begin{array}{l}\text { Pendapatan orang tua } \\
\text { merupakan penghasilan } \\
\text { yang di miliki orang } \\
\text { tua }\end{array}$ & $\begin{array}{l}\text { Pendapatan ayah dan ibu dalam Rp } \\
\text { satu bulan }\end{array}$ \\
\hline 5 & $\begin{array}{l}\text { Pendidikan } \\
\text { Orang Tua }\end{array}$ & $\begin{array}{l}\text { Pendidikan orang tua } \\
\text { adalah } \\
\text { sekolah yang ditempuh } \\
\text { orang tua }\end{array}$ & Jumlah tahun ayah bersekolah \\
\hline
\end{tabular}

\section{Metode Analisis Data}

Sebelum melakukan uji analisi pengaruh antara variabel bebas terhadap variabel terikat, terlebih dahulu dilakukan uji analisis regresi. Analisi regresi digunakan untuk melihat pengaruh antara variabel bebas dan variabel terikat, pada penelitian yang menggunakan satu variabel bebas dan variabel terikat maka digunakan metode analisis model regresi berganda dengan teknik analisis kuadrat terkecil sederhana (Ordinary Least Square(OLS) dengan bantuan aplikasi Eviews 10.

\section{HASIL DAN PEMBAHASAN}

\section{Lama Pendidikan Suami Responden}

Berdasarkan hasil penelitian terhadap 82 responden diperoleh data distribusi karakteristik responden dapat dilihat lama pendidikan suami :

Tabel 4 Lama Pendidikan Suami di Kecamatan Peranap Kabupaten Indragiri Hulu

\begin{tabular}{cccc}
\hline No & $\begin{array}{c}\text { Lama Pendidikan } \\
\text { (Tahun) }\end{array}$ & Jumlah Responden & $\begin{array}{c}\text { Persentase } \\
(\%)\end{array}$ \\
\hline 1 & 6 & 18 & 21,95 \\
\hline 2 & 9 & 46 & 56,10 \\
\hline 3 & 12 & 18 & 21,95 \\
\hline & Jumlah & 82 & 100,00 \\
\hline
\end{tabular}

Sumber: Data Olahan Primer, 2020

Bedasarkan Tabel 4 dapat diketahui bahwa lama pendidikan suami yaitu 6 tahun sebanyak 18 responden atau 21,95\%, selanjutnya sebanyak 46 responden atau 56,10\% memliki lama pendidikan 9 tahun dan sebanyak 18 responden atau 21,95\% memiliki lama pendidikan 12 tahun. 


\section{Lama Pendidikan Istri Responden}

Berdasarkan hasil penelitian terhadap 82 responden diperoleh data distribusi karakteristik responden dapat dilihat lama pendidikan istri :

Tabel 5.Lama Pendidikan Istri di Kecamatan Peranap Kabupaten Indragiri Hulu

\begin{tabular}{cccc}
\hline No & $\begin{array}{c}\text { Lama Pendidikan } \\
\text { (Tahun) }\end{array}$ & Jumlah Responden & $\begin{array}{c}\text { Persentase } \\
(\%)\end{array}$ \\
\hline 1 & 6 & 20 & 24,39 \\
\hline 2 & 9 & 47 & 57,32 \\
\hline 3 & 12 & 15 & 18,29 \\
\hline & Jumlah & 82 & 100,00 \\
\hline
\end{tabular}

Sumber: Data Olahan Primer, 2020

Bedasarkan Tabel 5 dapat diketahui bahwa lama pendidikan istri yaitu 6 tahun sebanyak 20 responden atau $24,39 \%$, selanjutnya sebanyak 47 responden atau 57,32\% memliki 9 tahun dan sebanyak 15 responden atau $18,29 \%$ memiliki pendidikan 12 tahun.

\section{Pendapatan Keluarga}

Berdasarkan hasil penelitian terhadap 82 responden diperoleh data distribusi karakteristik responden dapat dilihat pendapatan keluarga:

\section{Tabel 6 Total Pendapatan Keluarga di Kecamatan Peranap Kabupaten Indragiri Hulu}

\begin{tabular}{cccc}
\hline No & $\begin{array}{c}\text { Pendapatan } \\
(\mathrm{Rp})\end{array}$ & $\begin{array}{c}\text { Jumlah Responden } \\
\text { (1.200.000-1.300.000 }\end{array}$ & $\begin{array}{c}\text { Persentase } \\
(\%)\end{array}$ \\
\hline 1 & $1.301 .000-1.401 .000$ & 2 & 2,44 \\
\hline 2 & $1.402 .000-1.502 .000$ & 4 & 4,88 \\
\hline 3 & $1.503 .000-1.603 .000$ & 11 & 13,41 \\
\hline 4 & $1.604 .000-1.704 .000$ & 5 & 6,10 \\
\hline 5 & $1.705 .000-1.805 .000$ & 15 & 18,29 \\
\hline 6 & $1.806 .000-1.900 .000$ & 25 & 30,49 \\
\hline 7 & Jumlah & 20 & 24,39 \\
\hline
\end{tabular}

Sumber: Data Olahan Primer, 2020

Berdasarkan Tabel 6 dapat diketahui bahwa pendapatan keluarga berkisar antara Rp1.200.000 Rp1.900.000, dimana paling banyak responden memiliki pendapatan keluarga berkisar antara Rp1.705.000 - Rp1.805.000 yaitu sebanyak 25 responden atau 30,49\%, selanjutnya sebanyak 20 responden atau 24,39\% memiliki pendapatan keluarga berkisar antara Rp1.806.000 - Rp1.900.000. pendapatan keluarga berkisar antara Rp1.604.000 - Rp1.704.000 sebanyak 15 responden atau 18,29\%.

\section{Pendidikan Anak Dalam Keluarga}

Berdasarkan hasil penelitian terhadap 82 responden diperoleh data distribusi karakteristik responden dapat dilihat pendidikan anak:

Tabel 7 Pendidikan Anak di Kecamatan Peranap Kabupaten Indragiri Hulu

\begin{tabular}{clcc}
\hline No & Pendidikan & Jumlah Responden & $\begin{array}{c}\text { Persentase } \\
(\%)\end{array}$ \\
\hline 1 & SLTP/Sederajat & 27 & 32,93 \\
\hline 2 & SLTA/Sederajat & 55 & 67,07 \\
\hline & Jumlah & 82 & 100,00 \\
\hline
\end{tabular}


Sumber: Data Olahan Primer, 2020

Berdasarkan Tabel 7 dapat diketahui bahwa pendidikan anak terdiri dari sedang menjalani pendidikan SLTP/sederajat yaitu sebanyak 27 responden atau 32,93\%, dan sebanyak 55 responden atau $67,07 \%$ sedang menjalani pendidikan SLTA/sederajat.

\section{Bantuan PKH Pendidikan Anak Dalam Keluarga}

Berdasarkan hasil penelitian terhadap 82 responden diperoleh data distribusi karakteristik responden dapat dilihat pendidikan anak:

Tabel 8 Bantuan PKH Pendidikan Anak di Kecamatan Peranap Kabupaten Indragiri Hulu

\begin{tabular}{cccc} 
No & $\begin{array}{c}\text { Bantuan } \\
(\mathrm{Rp})\end{array}$ & $\begin{array}{c}\text { Jumlah Responden } \\
\text { Persentase } \\
(\%)\end{array}$ & $\begin{array}{c}\text { (\%) } \\
1\end{array}$ \\
125.000 & 27 & 67,07 \\
\hline 2 & 166.000 & 55 & 100,00 \\
\hline
\end{tabular}

Sumber: Data Olahan Primer, 2020

Berdasarkan Tabel 8 diketahui bantuan PKH diterima anak, tergantung dari pendidikan yang di jalani, dimana pendidikan anak yaitu SLTP/sederajat dan SLTA/sederajat, dimana sebanyak 27 responden atau 32,93\% memiliki bantuan PKH pendidikan anak sebesar Rp125.000 dan sebanyak 55 responden atau 67,07\% memperoleh bantuan pendidikan dari PKH sebesar Rp166.000.

\section{Persentasi Kehadiran Anak Di Sekolah}

Berdasarkan hasil penelitian terhadap 82 responden diperoleh data distribusi karakteristik responden dapat dilihat persentase sekolah anak:

Tabel 9 Persentase Kehadiran Sekolah Anak di Kecamatan Peranap Kabupaten Indragiri Hulu

\begin{tabular}{cccc}
\hline No & $\begin{array}{c}\text { Persentase Kehadiran Sekolah } \\
(\%)\end{array}$ & $\begin{array}{c}\text { Jumlah Responden } \\
\text { (\%) }\end{array}$ & $\begin{array}{c}\text { Persentase } \\
(\%)\end{array}$ \\
\hline 1 & $95-96$ & 19 & 23,17 \\
\hline 2 & $97-98$ & 57 & 69,51 \\
\hline 3 & $99-100$ & 6 & 7,32 \\
\hline
\end{tabular}

Sumber: Data Olahan Primer, 2020

Berdasarkan Tabel 9 diketahui persentasi kehadiran sekolah anak, berkisar antara 95\% sampai dengan 100\%. Dimana paling banyak anak sekolah memiliki persentase kehadiran berkisar antara 97\% 98\% yaitu sebanyak 57 responden atau 69,51\%, selanjutnya sebanyak 19 responden atau $23,17 \%$ memiliki persentase kehadiran sekolah anak berkisar antara 95\% - 96\%. Dan sebanyak 6 responden atau 7,32\% memiliki persentase kehadiran sekolah anak berkisar antara 99\% - 100\%.

\section{Prestasi Anak Di Sekolah}

Berdasarkan hasil penelitian terhadap 82 responden diperoleh data distribusi karakteristik responden dapat dilihat prestasi sekolah anak:

Tabel 10 Prestasi Sekolah Anak di Kecamatan Peranap Kabupaten Indragiri Hulu

No Prestasi Sekolah Anak Jumlah Responden Persentase

\begin{tabular}{cccc} 
& & $(\%)$ \\
\hline 1 & $68,00-70,50$ & 2 & 2,44 \\
\hline 2 & $70,60-73,10$ & 12 & 14,63 \\
\hline
\end{tabular}




\begin{tabular}{cccc}
\hline 3 & $73,20-75,70$ & 10 & 12,20 \\
\hline 4 & $75,80-78,30$ & 24 & 29,27 \\
\hline 5 & $78,40-80,90$ & 19 & 23,17 \\
\hline 6 & $81,00-83,50$ & 12 & 14,63 \\
\hline 7 & $83,60-86,10$ & 3 & 3,66 \\
\hline & Jumlah & 82 & 100,00 \\
\hline
\end{tabular}

Sumber: Data Olahan Primer, 2020

Berdasakan Tabel 10 dapat diketahui prestasi sekolah anak yang terlihat dari rata - rata nilai rapor anak sekolah, dimana berkisar antara 68,00\% sampai dengan $86,10 \%$. Dimana paling banyak responden memiliki prestasi sekolah anak berkisar antara 75,80 - 78,30 yaitu sebanyak 24 responden atau 29,27\%, selanjutnya sebanyak 19 responden atau 23,17\% memiliki prestasi sekolah berkisar antara 78,40 - 80,90. Masing - masing 12 responden atau 14,63\% memiliki prestasi sekolah anak berkisar antara 70,60 - 73,10 dan 81,00 - 83,50. Serta 10 responden atau 12,20\% memiliki prestasi sekolah anak berkisar antara 73,20 - 75,70. Paling sedikit sebanyak 2 responden atau 2,44\% memiliki prestasi sekolah anak berkisar antara $68,00-70,50$.

\section{Hasil Analisis Data}

\section{Uji F}

Uji simultan (uji F) bertujuan untuk melihat pengaruh variabel independen secara bersama-sama terhadap variabel dependen. Pengujian ini dilakukan dengan melihat nilai probabilitas signifikansi (sig) $\mathrm{F}$ yang dibandingkan dengan taraf nyata $\alpha=0,05$. Untuk lebih jelas dapat dilihat pada tabel berikut ini :

Tabel 11 Hasil Analisis Uji F

\begin{tabular}{lrr}
\hline & Uji Simultah (Uji F) & Coefficient \\
\hline Prob(F-statistic) & 0.000000 \\
\hline
\end{tabular}

Sumber: Data Olahan Eviews, 2020

Berdasarkan Tabel 11 diatas dapat di lihat tingkat probabilitas (F-Statistic) sebesar 0.000000. Hal ini berarti tingkat probabilitas (F-Statistic) sebesar 0,000000 lebih kecil dari nilai probabilitas (sig < 0,05), maka Ho ditolak dan $\mathrm{H}_{\mathrm{a}}$ diterima. Hal ini berarti bahwa pendidikan orang tua (X1), pendapatan orang tua (X2), persentase kehadiran sekolah anak (X3) dan bantuan PKH (X4) berpengaruh signifikan secara simultan terhadap prestasi pendidikan anak penerima Bantuan Program Keluarga Harapan di Kecamatan Peranap Kabupaten Indragiri Hulu.

\section{Uji Parsial (Uji t)}

Dalam penelitian ini uji parsial (uji t) digunakan untuk menguji seberapa jauh pengaruh satu variabel independen secara individual dalam menerangkan variabel dependen. Pengujian dilakukan dengan menggunakan signifikan level 0,05 $(\alpha=5 \%)$. Untuk lebih jelas dapat dilihat pada tabel berikut ini :

Tabel 12 Hasil Analisis Uji t (Uji Parsial)

\begin{tabular}{clc}
\hline No & Variable & Prob. \\
\hline 1 & Pendidikan_Orang_Tua & 0.0000 \\
\hline 2 & Pendapatan_Orang_Tua & 0.0000 \\
\hline 3 & Kehadiran & 0.0000 \\
\hline 4 & PKH & 0.0812 \\
\hline
\end{tabular}

Sumber: Data Olahan Eviews, 2020 
Berdasarkan Tabel 12 di atas hasil pengujian parsial masing-masing variabel bebas terhadap variabel terikat dalam penelitian ini adalah sebagai berikut:

1. Variabel pendidikan orang tua (X1)

Dari hasil pengujian hipotesis dapat diketahui bahwa pendidikan orang tua berpengaruh signifikan terhadap prestasi pendidikan anak penerima Bantuan Program Keluarga Harapan Di Kecamatan Peranap Kabupaten Indragiri Hulu pada tingkat 5\%.

2. Variabel pendapatan orang tua (X2)

Dari hasil pengujian hipotesis dapat diketahui bahwa pendapatan orang tua berpengaruh signifikan terhadap prestasi pendidikan anak penerima Bantuan Program Keluarga Harapan Di Kecamatan Peranap Kabupaten Indragiri Hulu.

3. Variabel persentase kehadiran anak sekolah (X3)

Dari hasil pengujian hipotesis dapat diketahui bahwa variabel persentase kehadiran anak sekolah berpengaruh signifikan terhadap prestasi pendidikan anak penerima Bantuan Program Keluarga Harapan Di Kecamatan Peranap Kabupaten Indragiri Hulu.

4. Variabel bantuan PKH (X4)

Dari hasil pengujian hipotesis dapat diketahui bahwa variabel bantuan PKH tidak berpengaruh signifikan terhadap prestasi pendidikan anak penerima Bantuan Program Keluarga Harapan Di Kecamatan Peranap Kabupaten Indragiri Hulu pada tingkat 10\%.

\section{Koefisien determinasi $\left(\mathbf{R}^{2}\right)$}

Untuk menentukan seberapa besar prediktor dapat menjelaskan variabel terikatnya dapat ditunjukkan dengan nilai koefisien determinasi yang diperoleh dari nilai Adjusted R-square. Hasil nilai Adjusted R-square dari regresi digunakan untuk mengetahui besarnya variabel dependen yang dipengaruhi oleh variabel independennya. Untuk lebih jelas dapat dilihat pada tabel berikut ini :

Tabel 12 Hasil Analisis Koefisien Determinasi

\begin{tabular}{cc}
\hline Keterangan & Coefficient \\
\hline Adjusted R-squared & 0.951942 \\
\hline
\end{tabular}

Sumber: Data Olahan Eviews, 2020

Berdasarkan hasil koefisien determinasi pada Tabel 5.15 menunjukkan nilai Adjusted R-square sebesar 0.951942. Hal ini berarti 95,1942\% variabel prestasi pendidikan anak penerima Bantuan Program Keluarga Harapan Di Kecamatan Peranap Kabupaten Indragiri Hulu dapat dijelaskan oleh variabel bebasnya yaitu pendidikan orang tua (X1), pendapatan orang tua (X2), persentase kehadiran sekolah anak (X3) dan bantuan PKH (X4) Sedangkan 4,8058\% dijelaskan oleh variabel lain diluar persamaan regeresi.

\section{Analisis Hasil Regresi Linear Berganda}

Berikut ini dapat dilihat hasil analisis regresi linear berganda yang bertujuan untuk menganalisis prestasi pendidikan anak penerima Bantuan Program Keluarga Harapan Di Kecamatan Peranap Kabupaten Indragiri Hulu dapat dijelaskan oleh variabel bebasnya yaitu pendidikan orang tua (X1), pendapatan orang tua (X2), persentase kehadiran sekolah anak (X3) dan bantuan PKH (X4) 
Tabel 13 Hasil Persamaan Regresi Linear Berganda

\begin{tabular}{lrr}
\hline & Variable & Coefficient \\
\hline Pendidikan_Orang_Tua & 0.493450 \\
\hline Pendapatan_Orang_Tua & $6.29 \mathrm{E}-06$ \\
\hline Kehadiran & 1.203891 \\
\hline PKH & $1.26 \mathrm{E}-05$ \\
\hline C & -56.76124 \\
\hline
\end{tabular}

Sumber: Data Olahan Eviews, 2020

Berdasarkan Tabel 13 diatas didapatkan persamaan regresi linear berganda sebagai berikut: $\mathrm{Y}=56.76124$ + 0.493450X1 + 6.29E-06X2 + 1.203891X3 + 1.26E-05X4

\section{Pengaruh Bantuan PKH Terhadap prestasi pendidikan anak penerima program keluarga harapan (PKH) di Kecamatan Peranap Kabupaten Indragiri Hulu.}

Pada penelitian ini, di Kecamatan Peranap, bantua PKH dapat mempengaruhi prestasi pendidikan anak, dan memiliki hubungan yang positif, artinya semakin meningkat jumlah bantuan PKH yang diterima anak sekolah maka akan meningkatkan prestasi sekolah anak yang terlihat dari nilai rata - rata rapor sekolah anak. Hasil penelitian ini sejalan dengan Rusydi (2016), dimana hasil penilaiannya menjelaskan bahwa Bantuan PKH mampu menjelaskan atau mempengaruhi partisipasi pendidikan anak anak.

Dalam mewujudkan pembangunan suatu daerah, maka salah satu pendorongnya adalah kulitas Sumber Daya Manusia yang terlihat dari tingkatan pendidikan (Isyandi, 2004), terjadilah campur tangan pemerintah dalam mewujudkannya yatu melalui pemberian bantuan tunai terutama di fokuskan untuk kemajuan tingkatan pendidikan masyarakat minimal hingga SLTA atau lama pendidikan 12 tahun.

Dengan kondisi seperti ini, orang tua tidak dapat dipersalahkan sepenuhnya, karena mereka tentu mempunyai alasan tersendiri dalam hal ini. Pelaksanaan wajib belajar selain menjadi hak dan kewajiban orang tua, juga menjadi hak dan kewajiban masyarakat dalam menyukseskan pelaksanaannya. Dan tak kalah pentingnya pelaksanaan wajib belajar menjadi hak dan kewajiban pemerintah. Demikian halnya peserta didik juga memiliki hak untuk mendapatkan biaya pendidikan bagi mereka yang orang tuanya tidak mampu untuk membiayai pendidikan mereka.

Hubungan antara bantuan program keluarga harapan (PKH) dengan prestasi anak sekolah yaitu dapat mendorong keinginan anak untuk sekolah. Pada dasarnya penerima bantuan PKH yaitu keluarga miskin, sehingga persolan biaya menjadi suatu kendala dalam menempuh pendidikan anak. Keluarga yang hanya mampu dalam memenuhi kebutuhan untuk makan sering kali harus mengorbankan pendidikan anak. Meskipun biaya sekolah sebagian besar telah gratis akan tetapi faktor pendukung sekolah yang tetap mengeluarkan biaya yang menjadi persolan yang di hadapi keluarga miskin seperti penyediaan buku dan alat tulis sekolah.

Sehingga dana dari bantuan program keluarga harapan (PKH) yang di pertujuan langsung untuk anak sekolah diharapkan mampu mengatasi persoalan tersebut, tujuan dari pemberian bantuan ini yaitu untuk meningkatkan pendidikan anak, tentunya dengan bantuan yang diterima maka anak yang bersekolah memiliki sarana penunjang dalam pendidikannya sehingga seharusnya kondisi tersebut akan mendorong anak untuk semakin giat lagi belajar yang nantinya akan terlihat dari prestasi yang diterima anak itu sendiri.

Dengan hasil penelitian yang menunjukkan hubungan antara bantuan program keluarga harapan $(\mathrm{PkH})$ yang memiliki korelasi positif tentunya hal tersebut berarti bahwa penerimaan bantuan PKH oleh anak sekolah dapat mendorong meningkatnya prestasi sekolah anak. Sehingga melihat kondisi demikian 
maka akan memunculka atau menciptakan anak - anak yang memiliki kualitas yang baik untuk masa depan.

\section{Pengaruh Kehadiran Anak Sekolah Terhadap prestasi pendidikan anak penerima program keluarga harapan (PKH) di Kecamatan Peranap Kabupaten Indragiri Hulu.}

Pengaruh persentase kehadiran terhadap prestasi anak sekolah dapat dilihat dari hasil analisis regresi linear berganda, dimana variabel persentase kehadiran anak sekolah berpengaruh signifikan terhadap prestasi pendidikan anak penerima Bantuan Program Keluarga Harapan Di Kecamatan Peranap Kabupaten Indragiri Hulu.

Muryono (2000) mengungkapkan ada dua hal yang mempengaruhi prestasi belajar antara lain faktor internal meliputi faktor yang berasal dari diri pribadi itu sendiri, begitu juga halnya dengan tingkat prestasi sekolah, dimana tingkat kehadiran anak tentunya akan mempengaruhi prestasi yang raih. Dimana semakin meningkat jumah kehadiran tentunya akan mendorong peningkatan prestasi anak sekolah.

Selain sebagai penentu tingkat prestasi anak sekolah, kehadiran juga merupakan pernilaian bagi anak penerima bantuan PKH. Tujuan PKH dalam bidang pendidikan adalah untuk meningkatkan angka partisipasi sekolah, khususnya bagi anak-anak Rumah Tangga Sangat Miskin (RTSM), serta untuk mengurangi pekerja anak. Untuk mencapai tujuan ini, PKH pendidikan berupaya memotivasi RTSM agar mendaftarkan anak-anaknya ke sekolah dan mendorong mereka untuk memenuhi komitmen kehadiran dalam proses belajar, minimal $85 \%$ dari hari efektif sekolah dalam sebulan, selama tahun ajaran berlangsung.

Jika dibandingkan dengan persentase kehadiran anak sekolah penerima bantuan PKH dimana persentasi kehadiran sekolah anak di Kecamatan Peranap Kabupaten Indragiri Hulu berkisar antara 95\% sampai dengan 100\%. Dimana angka kehadiran lebih besar dari komitmen kehadiran yang diharapkan dalam pemberian bantuan PKH yaitu $85 \%$.

Pengaruh pendapatan orang tua terhadap prestasi pendidikan anak penerima program keluarga harapan (PKH) di Kecamatan Peranap Kabupaten Indragiri Hulu

Pendapatan orang tua memiliki hubungan positif terhadap prestasi pendidikan anak penerima Bantuan Program Keluarga Harapan Di Kecamatan Peranap Kabupaten Indragiri Hulu, namun yang menjadi persoalan adalah tidak semua kondisi ekonomi keluarga itu sama, sehingga hal ini yang menjadi persoalan yang di hadapi oleh keluarga - keluarga miskin di Kecamatan Peranap. Sehingga jika hanya bergantung pada pendapatan orang tua tentunya kebutuhan pendidikan anak tidak akan terpenuhi.

Hasil penelitian ini sejalan dengan penelitian (Hadiyanto, 2014) menemukan hasil bahwa pendapatan orang tua berpengaruh signifikan terhadap prestasi belajar begitu juga dengan penelitian oleh (Menhard, 2017) yang mana menemukan hasil bahwa pendapatan orang tua berpengaruh terhadap pendidikan.

Pentingnya pendidikan dijelaskan oleh Emile Durkheim yang dikenal dengan teori Kompetisi yang menjelaskan bahwa tingginya pertumbuhan penduduk disuatu wilayah atau Negara akan mendorong terjadinya kompetisi dalam mempertahankan hidup. Dalam usaha memenangkan kompetisi ini setiap individu berusaha untuk meningkatkan pendidikan dan keterampilan dengan spesialisasi tertentu (Weeks, 1992).

Selain itu menurut Nurkse, pembangunan ekonomi berkaitan dengan kekayaan manusiawi, sikap sosial, kondisi politik dan latar belakang sejarah. Faktor - faktor tersebut menghalangi mobilitas sosial dan geografis untuk menerima nila - nilai baru yang lahir dari dampak pembaharuan. Menurut Jhingan (2016) keluarga merupakan unit ekonomi utama, sikap keluarga membatasi lingkungan kebebasan individu dalam pengambilan keputusan terutama dalam kebijakan terkait ekonomi dan memenuhi kewajiban sosial, salah satunya seperti sikap sosial terhadap pendidikan, dimana pendidikan akademis murni akan mempengaruhi pandangan seseorang terkait dengan kedudukan dan posisi lainnya dimasyarakat selain itu juga mengenai pengeluaran di bidang pendidikan. 
Sesuai dengan penjelasan sebelumnya, diketahui bahwa pendapatan orang tua merupakan penunjang pendidikan anak, semakin tinggi pendapatan orang tua maka kemampuan orang tua dalam mencukupi kebutuhan anak dalam pendidikan juga akan mengalami peningkatan.

\section{Pengaruh Pendidikan orang tua terhadap prestasi pendidikan anak penerima program keluarga harapan (PKH) di Kecamatan Peranap Kabupaten Indragiri Hulu}

Lingkungan keluarga (orang tua) merupakan pusat pendidikan yang pertama bagi seorang anak. Keluarga merupakan lembaga yang paling penting dalam membentuk kepribadian anak. Terlebih lagi keluarga mempunyai pengaruh yang sangat besar terhadap anak untuk berperilaku agresif atau tidak. Jadi, jika di lingkungan keluarga tersebut tertanam perilaku, budi pekerti, maupun kebiasaan sehari-hari yang baik maka seorang anak akan dapat pula tumbuh dan berkembang dengan baik, karena tujuan pendidikan di dalam keluarga adalah untuk membina, membimbing, dan mengarahkan anak kepada tujuan yang suci.

Dalam teori human capital yang dijelaskan oleh Frank dan Bernanke (2007) bahwa dalam teori human capita menjlaskan perpaduan antara pendidikan, pengalaman pendidikan yang dapat mempengaruhi produktivitas manusia, sehingga pendidikan menjadi salah satu faktor pending dalam mendukung kemajuan manusia salah satunya dalam meningkatkan produksitivitas.

Pendidikan orang tua tentunya akan mempengaruhi cara pandang orang tua dalam mendorong jalannya pendidikan yang ditempu oleh anaknya, semakin tinggi pendidikan orang tua maka pengetahuan orang tua akan pentingnya pendidikan juga akan semakin meningkat, sehingga dorongan untuk kualitas anak juga mengalami peningkatan. Saah stu wujud dari kualitas pendidikan anak terlihat dari pretasi belajarnya.

Prestasi belajar yang diperoleh oleh anak tidak lepas dari peran orang tua, mulai dari cara orang tua hanya mendampingi disaat anak belajar sampai dengan memanfaatkan ilmunya untuk ditularkan kepada anaknya. Cara dalam membimbing anak belajar dirumah akan berpengaruh terhadap prestasi belajar anak, sehingga anak di sekolah akan mempunyai prestasi belajar yang berbeda sesuai dengan bimbingan yang diperoleh anak dari orang tuanya. Orang tua dengan tingkat pendidikan yang lebih tinggi juga memungkinkan untuk lebih percaya diri pada kemampuan mereka dalam membantu anak-anak mereka belajar.

Dengan tingkat keyakinan tersebut maka diperkirakan akan berpengaruh secara signifikan terhadap kemampuan akademis anaknya. Sebab, semakin tinggi tingkat pendidikan orang tua makan akan bertambah luas pandangan dan wawasan termasuk dalam mengatur keluarganya. Jadi orang tua dengan pendidikan tinggi akan dapat lebih memperhatikan ketercapaian prestasi belajar anaknya dibandingkan dengan orang tua yang berpendidikan rendah.

\section{Implementasi Kebijakan Terkait Prestasi Pendidikan Anak Penerima Bantuan Program Keluarga Harapan (PKH) di Kecamatan Peranap}

Pendidikan merupakan salah satu indikator yang sangat penting dalam menciptakan sumber daya yang berkualitas. Pentingnya pendidikan ini yang mendorong pemerintah pusat maupun pemerintahan daerah melakukan berbagai kebijakan untuk meningkatkan standard an kualitas pendidikan. Namun kondisi yang terjadi masih adanya anak putus sekolah. Penyebab terjadinya putus sekolah antara lain adalah karena faktor ekonomi, minat peserta didik untuk bersekolah yang rendah, perhatian orang tua yang kurang, fasilitas belajar yang kurang mendikung serta faktor budaya dan lokasi atau letak sekolah.

Pendidikan menjadi salah satu indicator penting dalam mewujudkan pembangunan baik dari aspek ekonomi maupun aspek sosial, untuk mewujudkan suatu daerah atau Negara yang memiliki kekayaan akan ketersediaan SDM yang berkualitas maka yang sangat mendukung adalah kualitas pendidikan.

Di dalam RPJMD bidang pendidikan Provinsi Riau menjelaskan bahwa Faktor ekonomi merupakan faktor pertama penyebab anak putus sekolah. Ketidakmampuan keluarga anak untuk 
membiayai segala proses yang dibutuhkan selama menempuh pendidikan atau sekolah dalam satu jenjang tertentu. Pencanangan dan pelaksanaan program pendidikan menengah universar belum berimplikasi secara maksimal terhadap penurunan jumlah anak putus sekolah .

Pada saat ini telah terdapat petugas - petugas pendamping yang memonitoring keluarga penerima bantuan $\mathrm{PKH}$, terdapat berbagai kualifikasi yang menjadi pertimbangan suatu keluarga beserta anggota keluarga dapat menerima bantuan PKH. Namun, jika hanya sekedar memantau saja tentunya hal terjadi adalah mendorong masyarakat miskin tetap terjebak didalam kemiskinan yang pada akhirnya terus bergantung dari bantuan yang diterima pemerintah, hal ini tentunya berlawanan dengan tujuan dasar dari program keluarga harapan $(\mathrm{PKH})$ itu sendiri.

Sehingga pemerintah diharapkan sedikit menambah sasaran yang ingin di capainya, diantaranya pendamping keluarga penerima $\mathrm{PKH}$ tidak lagi hanya memantai atau memotoring tetapi lebih ke membina dan mengembangkan kualitas masyarakat itu sendiri. Salah satunya dalam kajian ini membahas anak sekolah. Tentunya hasil akhir bukan anak tersebut menamatkan pendidikannya minimal 12 tahun atau setara SLTA/sederajat, tetapi dapat melanjutkan ke perguruan tinggi ataupun siap bekerja setelahnya.

\section{KESIMPULAN}

Berdasarkan hasil penelitian dan pembahasan maka dapat ditarik kesimpulan dalam penelitian ini sebagai berikut :

1. Bantuan program keluarga harapan $(\mathrm{PKH})$ berpengaruh signifikan positif terhadap prestasi pendidikan anak penerima program keluarga harapan $(\mathrm{PKH})$ di Kecamatan Peranap Kabupaten Indragiri Hulu.

2. Tingkat kehadiran anak berpengaruh signifikan positif terhadap terhadap prestasi pendidikan anak penerima program keluarga harapan $(\mathrm{PKH})$ di Kecamatan Peranap Kabupaten Indragiri Hulu.

3. Pendapatan orang tua berpengaruh signifikan positif terhadap terhadap prestasi pendidikan anak penerima program keluarga harapan $(\mathrm{PKH})$ di Kecamatan Peranap Kabupaten Indragiri Hulu.

4. Tingkat pendidikan orang tua berpengaruh signifikan positif terhadap terhadap prestasi pendidikan anak penerima program keluarga harapan $(\mathrm{PKH})$ di Kecamatan Peranap Kabupaten Indragiri Hulu.

\section{SARAN}

Berdasarkan uraian kesimpulan diatas, maka dapat dirumuskan saran dalam penelitian ini sebagai berikut :

1. Pemerintah sebagai pihak yang berwenang dalam penyaluran bantuan PKH diharapkan dapat tepat sasaran dan benar-benar ditujukan untuk meningkatkan pendidikan anak, karena bantuan PKH dapat mendorong prestasi pendidikan anak penerima program keluarga harapan ( $\mathrm{PKH})$ sehingga yang membutuhkan suntikan dana dapat memenuhi keutuhan pendidikan. Hal ini penting, karena bantuan tersebut hanya bersifat sementara dan lebih terfokus untuk memutuskan mata rantai kemiskinan setelah itu tidak diberikan lagi. Bantuan PKH yang diterima anak, sebaiknya juga dialokasikan untuk asupan anak terutama dalam menunjang kesehatan anak, sehingga anak penerima bantuan PKH juga memiliki kemampuan fisik untuk selalu hadir setiap pembelajaran yang dilakukan.

2. Bantuan PKH yang bersifat sementara, maka diharapkan masyarakat penerima bantuan tidak hanya menerima suntikan dana karena hal tersebut terkesan memaksa keluarga dari kemiskinan, sehingga sebaiknya perolehan bantuan $\mathrm{PKH}$ juga dialokasi oleh rumah tangga untuk kegiatan yang produktif. PKH tidak lagi hanya sekedar suntikan dana mendorong pemenuhan kebutuhan tetapi juga sebagai media pemberdayaan masyarakat yang produktif. 
3. Orang tua sebagai madrasah pertama bagi anak, diharapkan memegang peranan penting dalam pendidikan anak, dengan cara mendorong minat dan semangat anak untuk menjalankan pendidikan dan meraih prestasi belajar yang baik. Selain itu, sebaiknya orang tua juga turut aktif dalam memantau perkembangan pendidikan anak. Dengan demikian akan lebih cepat mendorong terciptanya tenaga kerja yang berkualitas dimasa yang akan datang.

4. Pemerintah sebagai pihak pemegang wewenang dalam mengambil suatu kebijakan diharapkan dapat menciptakan anak penerima PKH tidak hanya sebatas menyelesaikan pendidikan hingga 12 tahun atau SLTA tetapi juga menciptakan anak yang memiliki skill siap masuk pasar kerja serta menyediakan suatu fasilitas bagi anak yang memiliki kualitas tertentu untuk dapat melanjutkan pendidikan ke tahap selanjutnya.

\section{DAFTAR PUSTAKA}

[1] Ani, D., \& Marbuah, A. (2016). Influence of Parental Income and Educational Attainment on Children's Years of Schooling:Case of Ghana. Master's thesis in Sociology of Education .

[2] Dulkiah, M., Sari, A. L., \& Irwandi. (2018). The Impact of Conditional Cash Transfer (CCT) to Socio-Economic of Poor Families; A Case Study. Jurnal Ilmu Sosial Mamangan 7(1) , 32 - 39.

[3] Frank, R. H., \& Bernanke, B. S. (2007). Principles of Microeconomics (3rd ed.). New York: McGraw-Hill/Irwin.

[4] Hadiyanto, H. (2014). Pengaruh Pendidikan, Pekerjaan Dan Pendapatan Orang Tua Terhadap Prestasi Belajar Ekonomi Pada Siswa SMA. Jurnal Ekonomi Pendidikan Dan Kewirausahaan 2 (2) , 171 185.

[5] Hamalik, O. (2002). Psikologi Belajar Mengajar. Bandung: Sinar Baru Grasindo.

[6] Harsono. (2011). Etnografi Pendidikan sebagai Desain Penelitian Kualitatif. Surakarta: Universitas Muhammadiyah Surakarta.

[7] Isyandi. (2004). Manajemen Sumber Daya Manusia Dalam Perspektif Global. Pekanbaru: Unri Press.

[8] Isyandi, B. (2014). Ekonomi Regional : Teori dan Penerapan. Cetakan ke 1. Pekanbaru: Unri Press.

[9] Jhingan, M. L. (2016). Ekonomi Pembangunan dan Perencanaan. Jakarta: Rajagrafindo Persada.

[10] Menhard. (2017). Pengaruh Pendapatan Orang Tua Dan Status Sosial Terhadap Minat Melanjutkan Pendidikanke Perguruan Tinggi (Studi Kasus Stiemahaputra Riau). Jurnal Wira Ekonomi Mikroskil $7(1), 45-52$.

[11] Mulyadi, S. (2017). Ekonomi Sumber Daya Manusia Dalam Perspektif Pembangunan. Jakarta: Raja Grafindo Persada

[12] Muryono. (2000). Pengaruh Persepsi Siswa Tentang Tugas Guru Terhadap Prestasi Belajar Bidang Studi Matematika. Jurnal Anima 15 (3) , 246 - 254. 
[13] Notoatmodjo, S. (2015). Pengembangan Sumber Daya Manusia. Cetakan Keempat. Edisi Revisi. Jakarta: Rineka Cipta.

[14] Robbins, S. P., \& Coulter, M. (2010). Manajemen Edisi Kesepuluh. Jakarta: Erlangga.

[15] Soekidjan. (2009). Manajemen Sumber Daya Manusia. Jakarta: Bumi Aksara.

[16] Suparno. (2018). Analisis Pemberian Bantuan Sosial Program Keluarga Harapan Terhadap Prestasi Belajar Anak Di Kecamatan Sepauk. Jurnal Pekan 3(2), 177 - 185.

[17] Todaro, P. M., \& Smith., S. C. (2013). Pembangunan Ekonomi. Jakarta: Erlangga.

[18] Weeks, J. R. (1992). Population. California: Wadsworth. 